\title{
$\equiv$ Preface $\equiv$
}

began work on this book several years ago as a graduate student at UCLA. It struck me at the time that few serious historians had examined southern California's rich urban past; although the butt of many jokes, Los Angeles remained a largely under-studied environment. I started examining Los Angeles with the intention of explaining why this city differs so much from many other cities. I found, in fact, that southern California shares many characteristics with other metropolitan areas. Los Angeles, then, is important not because it is a unique city but because its history helps explain the evolution of America's urban development. This work therefore explores not only the history of Los Angeles over the past eighty-five years, but also that of all American urban areas.

Although writing this book was largely a solitary effort, I have accumulated many debts over the last six years. First, I would like to thank the staffs of several libraries who helped uncover much of this city's past, including: the University Research Library of UCLA, the Los Angeles Municipal Research Library, the Los Angeles Public Library, and Special Collections of UCLA. I would especially like to thank Robert Middlekauff, Martin Ridge, and the entire staff of the Henry E. Huntington Library in San Marino. Not only did the Huntington yield important documents for my scrutiny but it also provided me with a halcyon atmosphere in which to write most of my manuscript. 
Despite the fact that Los Angeles is often accused of ignoring its past, the city holds within its boundaries several important photographic collections. I would like to thank several of these archives for allowing me to reproduce the photographs that illustrate this book. These include: the Security Pacific National Bank Photograph Collection in the Los Angeles Public Library; the Seaver Center for Western History Research in the Natural History Museum of Los Angeles County; the Los Angeles City Archives; Special Collections of the University Research Library, UCLA; the California Historical Society; the Spence Air Photo Collection at the Department of Geography, UCLA; and the Huntington Library.

Several organizations at UCLA provided me with research funds that enabled me to pursue this project. I would therefore like to thank the Department of History, the Alumni Association, the College of Letters and Science, and the Department of Fellowships and Grants.

Most important, I owe a debt of gratitude to several people who read and criticized this work at various times. Stanley Holwitz at the University of California Press took an early interest in this book and helped guide it through the publication process. David Dexter and Shirley Warren gave my manuscript a thorough reading and saved me from many typographical and grammatical errors. Martin Wachs and Norris Hundley not only read an earlier version of this work but also served on my doctoral committee. Dr. Wachs's knowledge of urban transportation planning was particularly helpful and I thank him for his encouragement. I would also like to thank Jaclyn Greenberg, David Johnson, Kenneth Jackson, Joel Tarr, Roger Lotchin, and Larry Lipin for their careful readings of my manuscript and their suggestions for improvement.

Eric Monkkonen served as a mentor, friend, and eventually as my dissertation chairman. Dr. Monkkonen was a model mentor. He challenged and advised me without inter- 
fering with my independence. The fact that I wrote a nonquantitative study alone speaks of Dr. Monkkonen's broadminded approach to graduate studies.

In reading countless acknowledgment pages of other authors, I am struck by the fact that one's spouse is almost always the last to be thanked. Ironically, I am following in that tradition. Yet I thank Catherine Kelly not for her typing skills, but for her intellectual contributions to this work. A historian in her own right, Catherine has several times put aside her own book manuscript to read and criticize the pages that follow. I therefore thank her for her efforts on my behalf and for her steadfast support while I was struggling to establish myself in a new career. 
This page intentionally left blank 